\title{
INSTITUTIONAL SUPPORT FOR BIOGAS ENTERPRISES - THE LOCAL PERSPECTIVE
}

\author{
JusTYNA CHODKOWSKA-MiszCZuK \\ Department of Urban and Regional Development Studies, Faculty of Earth Sciences, \\ Nicolaus Copernicus University, Toruń, Poland
}

Manuscript received: January 24, 2019

Revised version: March 25, 2019

\begin{abstract}
СноркошSкA-Miszczuк J., 2019. Institutional support for biogas enterprises - the local perspective. Quaestiones Geographicae 38(2), Bogucki Wydawnictwo Naukowe, Poznań, pp. 137-147. 5 figs.

ABSTRACT: Institutional support, reflected not only in legislative solutions, but also in external funding as a means of financial support, is of strategic importance for the success of new power investments, the guarantee of energy security of individual areas, and the socio-economic development of the region where new energy enterprises are located. The present study aims to follow the external funding of biogas investments carried out in Poland, both in the aspect of legal regulations, and the offered co-financing of biogas projects. Considering that biogas enterprises are located and operate in specific places and local systems, the present research problem is tackled from the perspective of the functioning of biogas plants in the local environment. The success of biogas projects and the entire energy transformation process depends, on the one hand, on the harmonisation of activities at the central, national level and, on the other hand, on taking into account the specific socio-economic features that characterise the location of the biogas plant. Therefore, providing comprehensive institutional support for investment for biogas enterprises requires equipping local institutions, including local authorities, with appropriate instruments to shape and monitor the agricultural biogas market at the local level.
\end{abstract}

KEY WORDS: biogas, energy policy, institutional, support, local development, renewable energy sources

Corresponding author: Justyna Chodkowska-Miszczuk, Department of Urban and Regional Development Studies,

Faculty of Earth Sciences, Nicolaus Copernicus University, Lwowska 1, 87-100 Torun, Poland; e-mail: jchodkow@umk.pl

\section{Introduction}

Energy transformation, manifested in the transition from a centralised energy industry using conventional raw materials to a decentralised model based on renewable energy sources (RES), requires multifaceted actions set in an institutional framework. Institutional support, reflected not only in legislative solutions, but also in external funding as a means of financial support, is of strategic importance for the success of new power investments, the guarantee of energy security of individual areas, and the socio-economic development of the region where new energy enterprises are located.

Public aid is indispensable for two reasons. Firstly, the implementation of ventures in the field of RES bears investment risks primarily due to the fact that current energy systems are organised in order to support the production and distribution of energy generated centrally by large energy actors. The long-term technological and institutional evolution leading to the establishment of an energy sector based on relatively 
large power units using hard coal, named by G.C. Unruh (2000) carbon lock-in, dramatically impedes the proliferation of smaller facilities generating RES-based energy. The widespread use of coal and crude oil is a pivotal aspect of capitalist production methods. M.T. Huber (2009) goes as far as to call it 'fossil capitalism'. Access to fossil fuels ensuring the uninterrupted production of energy used in all spheres of socio-economic activity and guaranteeing comfortable living space may lead to the formation of a lifestyle defined as the hydro-carbon man (Shaffer 2009).

The second type of factors backing the need for public support for RES-based energy investments are of historical and political nature. The issue of energy security is paramount in central European countries undergoing changes related to the energy sector transformation, including the dissemination of RES. Poland's presence in the European Union (EU) is connected with the need to implement changes in the energy sector reflecting the EU cohesion policy and manifested by the diversification of energy sources as well as the growing role of RES (ChodkowskaMiszczuk et al. 2016). In accordance with the provisions of Directive 2009/28/EC, EU member states are obliged to increase the role of RES in the energy production structure by $20 \%$ by 2020 . Moreover, the long-term EU energy policy assumes full decarbonisation of the energy sector by 2050 (Ruester et al. 2013). The range and pace of those transformations are determined by the complicated historical and political past of central European countries, including Poland, which is nowadays reflected in the domination of one energy source (e.g. coal in Poland), the centralisation of the energy sector along with energy dependence on Russia (Kats 1991; Buzar 2007). In the light of the above, Poland's implementation of the EU climate and energy policy objectives translates into numerous legislative, planning, organisational and investment projects carried out on different levels of administration, both at national and local levels.

It is crucial to refer to the local level which gives the whole picture of transitions resulting from the emergence of new energy enterprises dealing with RES-based energy production. New energy actors are visible both in urban and rural areas; however, due to a number of factors, e.g. raw material resources for energy production and the availability of potential locations for those entities, such investments are predominantly carried out in rural areas (ChodkowskaMiszczuk 2014). Therefore, bearing in mind the energy sector transformation and the local development of rural areas, it is worth directing research at issues related to those energy sources whose use provides the widest-ranging boost to the socio-economic development of rural areas and the functional diversification of agriculture. Such activities include biogas energy generation in agricultural biogas plants (Jasiulewicz 2010; Wirth et al. 2013). Agricultural biogas plants are distinct from other renewable energy technologies. Their operation is the most predictable among all RES plants: biogas energy production is not conditioned on natural factors to the same degree as in the case of, e.g. wind, water or solar power plants (Bluemling et al. 2013; Wirth et al. 2013). Similar to any other RES, the production of agricultural biogas currently depends on public aid. Consequently, the present study aims to follow the external funding of biogas investments carried out in Poland, both in the aspect of legal regulations, and the offered co-financing of biogas projects. Considering that biogas enterprises are located and operate in specific places and local systems, the present research problem is tackled from the perspective of the functioning of biogas plants in the local environment.

\section{Materials and methods}

A two-stage research procedure was applied in order to reach the above-mentioned research objective. In the first stage, the author used the desk research method to analyse existing documents and databases regarding legal regulations in force as well as different forms of public aid in the scope of agricultural biogas energy production. The state and international legislation and information on financial support obtained for biogas investments were analysed: both from Polish and EU sources (2007-2013), available in the National IT System (NITS, 2007-2013), and databases of the National Fund for Environmental Protection and Water Management (NFEP\&WM).

The second stage of the research consisted in the empirical analysis of selected locations 
housing agricultural biogas plants co-financed from external sources. Two biogas plants were chosen for that purpose: (1) in Buczek (the Jeżewo commune, Kujawsko-Pomorskie Voivodeship) and (2) in Działyń (the Kłecko commune, Wielkopolskie Voivodeship). The first of the above-mentioned biogas plants is an investment subsidised from the Operational Programme Infrastructure and Environment, OP I\&E UE (2007-2013), while the second was co-funded by the National Fund for Environmental Protection and Water Management (NFEP\&WM). The enterprises also differ in terms of the adopted business model. The Buczek biogas plant (with a capacity of $1.8 \mathrm{MW}$ ) operates as a separate business entity and the Działyń plant (0.999 MW) as a part of an existing agricultural enterprise. In order to gain in-depth knowledge of the significance of public aid in the operation of biogas enterprises and their functioning in the local environment, the author also referred to methods allowing her to gain information directly from the local community (Lutyński 2000). Therefore, the qualitative approach was applied, because it is the only way to search for meanings and discover the grounds on which a community acts, considering and understanding what the respondents imagine, how they perceive reality and what they consider significant (Hammersley 1992; Wójcik et al. 2018). In view of that, interviews were carried out with representatives of the biogas plants and the local environment, including local institutions, NGOs, enterprises and residents. A total of 15 interviews were conducted on the assumption that the respondents represent the different spheres of political, social and economic local life and are aware of the subject related to the studied biogas plants. On-site research was preceded by a query needed in order to prepare the scenario of in-depth interviews and arrange meetings with respondents. The interviews were carried out between June and September 2017. Each interview lasted between one and one and a half hours or until the topic was exhausted. The interviews were conducted according to the interview guide focused on the circumstances of launching the biogas plant operation, dimensions of interactions with local authorities, locals, as well as social awareness and perception of biogas plants by local people.

\section{Research results}

\section{Legal and financial aspects of RES}

The energy sector is subject to international and national policies (Mitchell 2004). Therefore, the process of its transformation, including also the use of individual renewable sources (water, wind, solar energy, geothermal energy, biomass and biogas) for energy purposes, is conducted by relevant regulations at international and national levels. Poland's membership in the EU is related to the implementation of changes in the energy sector reflecting the EU cohesion policy (ChodkowskaMiszczuk et al. 2016). Nonetheless, the type of energy culture predominant in this area (Stephenson et al. 2010; Łucki, Misiak 2010; Lawson, Williams 2012), considered, inter alia, through the structure of sources used for energy production, influences the diversified level of the RES use worldwide, including in the EU member states. Hence, objectives set for an individual EU member states vary, e.g. for Poland it is a $15 \%$ share of renewable sources in energy production in 2020 (Fig. 1).

The directions of changes in the energy sector at the national level are provided for in relevant strategic documents and regulations, including first and foremost the Act of 20 February 2015 on renewable energy sources which determines the shape of the Polish energy sector, both in relation to the structure of energy sources, and the size of new energy actors. In accordance with the definition contained in the Act, RES are non-fossil sources of energy covering wind energy, solar energy, aerothermal energy, geothermal energy, hydrothermal energy, hydropower, wave energy, tidal energy, energy obtained from biomass, biogas, agricultural biogas and bioliquids. Among the subsequent amendments to the Act of RES, including switch to the auctioning system of sale of electricity (Chodkowska-Miszczuk et al. 2017), it is worth pointing to this one (1st of July 2016) defining the mechanism of support for agricultural biogas plants called 'blue certificates'. These are certificates of energy origin for electricity generated from agricultural biogas.

European funds are a tool to fulfil the EU priorities in the scope of directions of energy development, including the increase in the use of renewable sources. These funds help create equal opportunities not only for countries, but also 
[\%]

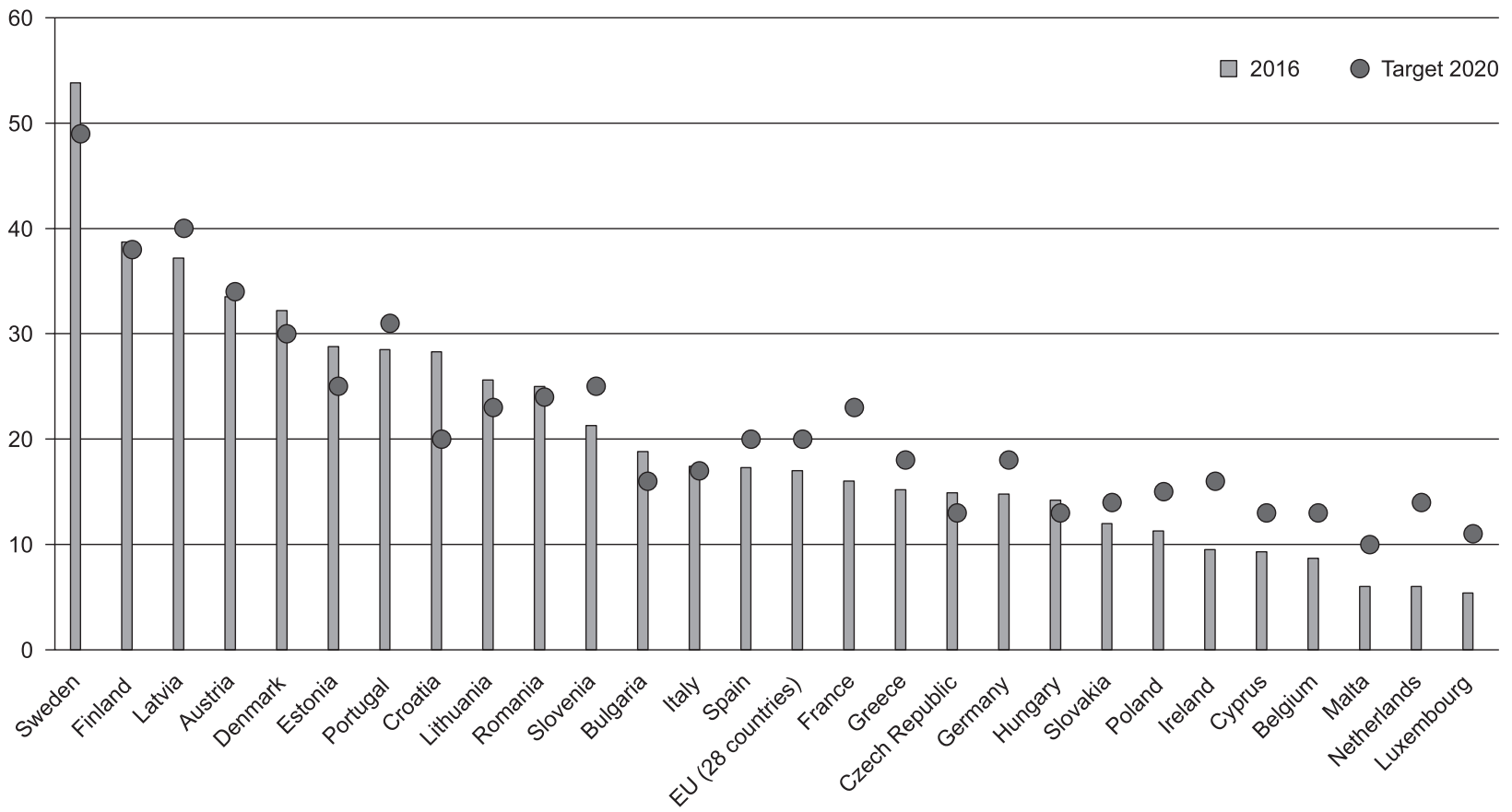

Fig. 1. The share of RES in gross final energy consumption in the EU countries together with the 2020 target. Source: own study based on Eurostat data, 2018.

for European regions, and thus increase social, economic and territorial cohesion of the whole EU. RES development received extremely broad support in the 2007-2013 financial perspective. The total value of the RES projects co-financed from EU funds has amounted to 2 billion euro, i.e. $2 \%$ of the value of all projects implemented in Poland and subsidised by EU funds during the programming period 2007-2013. The money was spent as part of the implementation of the Cohesion Policy (Cohesion Fund, European Regional Development Fund) and the Common Agricultural Policy (European Agricultural Fund for Rural Development) (ChodkowskaMiszczuk et al. 2016). In Poland, funds for this purpose - about one billion euros - were found in 16 Regional Operational Programmes (ROP), two Operational Programmes: Infrastructure and Environment (OP I\&E) and Human Capital (OP HC), as well as in the Rural Development Programme (RDP) - mainly in the context of measures related to functional diversification of agriculture and multifunctional development of rural areas (NITS, 2007-2013).

An efficient transformation of the Polish energy sector resulting from the initiation of relevant legislative and financial tools (European and national) requires activity in different spatial systems; however, the most important and the most comprehensible actions are carried out at the local level through the emergence of new RES-based energy actors. Agricultural biogas plants operating in rural areas are favourable example of such entities. They produce energy (electricity and heat) on the basis of agri-food production waste and/or energy crops. They are established both as individual businesses and within existing agri-food enterprises, mainly large-area farms operating within the boundaries of former State Agricultural Farms. Their number is systematically growing, so that at the end of 2018 there were 96 agricultural biogas plants in Poland (Woźniak 2017, Internet source 1).

When considering completed investments in the field of agricultural biogas energy production in Poland, it should be noted that the major part of them has been established using external funding. European funds are the most important source of funding. Around one fourth of the agricultural biogas plants in operation have emerged thanks to subsidies provided both in the ROPs of individual voivodeships, and Operational Programmes: OP I\&E and OP HC. The total value of biogas projects co-funded from EU funds is over $5 \%$ of the value of all renewable energy ventures in Poland and 30\% of bioenergy 
investments subsidised from EU programmes. The total amount of EU co-financing obtained for the construction of agricultural biogas plants amounts to over $6 \%$ of all subsidies spent on the dissemination of RES installations in Poland and over $40 \%$ of bioenergy projects which received EU support (NITS, 2007-2013).

In turn, nearly one fifth of biogas investments are the result of co-financing from the National Fund for Environmental Protection and Water Management - the National Green Investment Scheme (GIS) Operator, offering, for instance, support for the construction of agricultural biogas plants. GIS is an international emissions trading mechanism based on the proceeds from the sale of Assigned Amount Units (AAU). Funds from those transactions fuel green investments, including, e.g. agricultural biogas plants. The primary objective of this instrument is to form a system serving both environmental and socio-economic development of a given area (Kierzkowska 2011).

Other sources of funding biogas projects include own funds and other forms of aid not directly related with the establishment of biogas plants, but launched more with a view to support non-energy sectors of the economy, e.g. the Polish Sugar Industry Restructuring Programme referring to the reconstruction of the sugar industry in the whole EU. In accordance with the provisions of the National Restructuring Programme, funding may be applied to, e.g. measures enabling agricultural products to be processed for energy purposes, i.e. leading to the establishment of agricultural biogas plants (Sprawozdanie... 2013).

The analysis indicates that external support was provided both to large biogas plants whose installed capacity oscillates around $2 \mathrm{MW}$ (e.g. the Buczek plant) or even exceeds it, and to smaller facilities with a capacity of around $0.5 \mathrm{MW}$ (e.g. the Działyn plant). In terms of the geographical context of the subsidised biogas plants, investments co-funded by NFEP\&WM are spatially concentrated in five voivodeships, while plants financed from EU structural funds are located in twelve voivodeships. There is a clear division of the country into the area where EU-funded biogas plants operate (mainly eastern Poland) and the area with plants whose construction was financially supported by NFEP\&WM (primarily western Poland). The spending of EU structural funds contributed to the establishment of biogas enterprises in Podlaskie (5) and Lubelskie (3) Voivodeships, but also in Zachodniopomorskie, Kujawsko-Pomorskie and Warmińsko-Mazurskie Voivodeships. On the other hand, funds from NFOŚiGW were obtained for the construction of biogas plants located mainly in western Poland, i.e. in Wielkopolskie (8) and Dolnośląskie (5) Voivodeships, but also in Pomorskie and Zachodniopomorskie Voivodeships.

The biogas plants selected for empirical analysis are entities constructed with the help of external funds, both from NFEP\&WM (the Działyn plant), and the EU fund OP I\&E 2007-2013 (the Buczek plant). Public aid obtained in the form of subsidies at the investment stage was a major help in both the launching of the biogas plants studied, and their functioning which depends on continued financial support and existing systemic solutions at the national level. Considering that the operation of the plants is also dependent on public aid, any changes in the scope of the support will be reflected also in the socio-spatial dimension of the operation of biogas plants. The results of interviews carried out both with owners/ managers of the plants, and the representatives of the local community proves that institutional arrangements are pivotal to the operation of biogas plants in local systems in which they are located. From the perspective of the economic efficiency of a biogas enterprise, particular attention is paid to systemic institutional solutions reflected in concrete initiatives that guarantee genuine support for agricultural biogas plants in Poland, at the political, legislative, as well as procedural level. In the political sphere, of key importance is the shaping of a long-term and stable RES energy

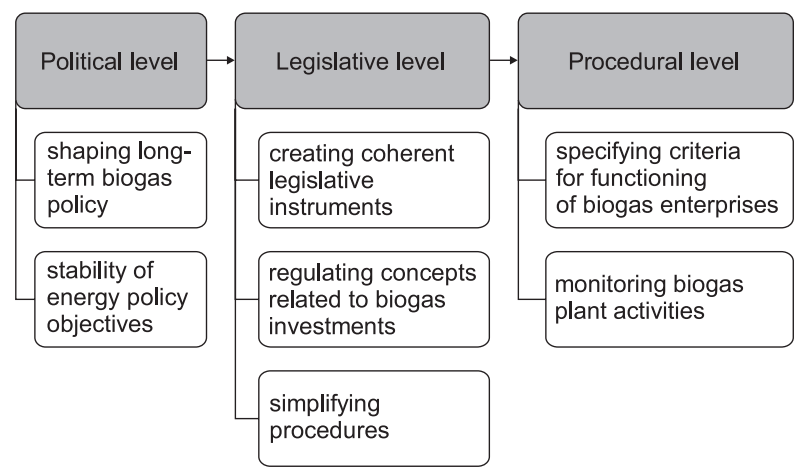

Fig. 2. Synergy of institutional solutions for the biogas market in Poland.

Source: own study based on research results. 
policy consistent with EU guidelines. At the legislative level, it is paramount to regulate the terms and concepts related to a comprehensive approach to biogas investments, to formulate a precise and clear definition of an agricultural biogas plant and specify the criteria for its functioning. With regard to procedures, there is a need to optimise tools and also to reinforce the multilayered monitoring of the activities of plants considering not only general external rules, but also the specific features of the location of an investment, i.e. the local context (Fig. 2).

\section{Functioning of biogas plants in the opinion of locals}

In addition to creating coherent policy, legislative and procedural instruments to manage the biogas energy segment, external support also includes financial guarantees (Fig. 3). Significant fluctuations in the amount of subsidies offered by central authorities affect not only the current decisions of biogas investors, but can and do have repercussions in relations with the local community. The most important factor here is the lack of stability in the amount of subsidies for the purchase of so-called "green energy":

"If biogas plants were to operate on the basis of green certificates, we would have had to close down our business long ago" (a biogas plant representative).

Annual decreases in the value of green certificates, i.e. certificates of origin for electricity from RES which were to be the leading source of profit for both companies in their business plans, result in continuous changes in their operation affecting interactions with the local environment (Chodkowska-Miszczuk et al., 2017). The green certificate system operated unchanged until the mid-2016. Then, in accordance with the provisions of the Renewable Energy Sources Act, new rules of support for energy actors using RES, namely auctions, were introduced. Auctions for agricultural biogas plants are conducted in a separate pool, in two parallel groups. The first group includes installations up to $1 \mathrm{MW}$, while the second group includes entities with a capacity above 1 MW. The defined criterion separating these two groups is reflected in the structure of agricultural biogas plants according to installed capacity. Half of the biogas plants co-financed by the National Fund for Environmental Protection and Water Management and a significant part of the companies subsidised by EU structural funds are distinguished by cap installed capacity of $0.999 \mathrm{MW}$. The size of the biogas plant not exceeding $1 \mathrm{MW}$ is to ensure operation in the auction group for smaller installations. The situation on the biogas market was slightly improved by the emergence of another financial instrument, the so-called "blue certificates". They represent an obligation to purchase electricity produced in agricultural biogas plants:

"The situation on the RES market was tragic until the entry into force of the blue certificates" (a biogas plant representative).

The reduction of purchase prices of energy produced from agricultural biogas and other RES had a direct impact on the decreasing economic condition of biogas plants. Companies which at the investment stage received external financial support obliging them to repay the loan or to maintain the subsidised activity for a period of several years after the start-up of the facility are in a peculiar situation:

"This is frozen EU money and the protection period so nothing can be upgraded there" (a local leader) (Fig. 3).

As a result, apart from cost reduction, a search was started for new developmental impulses

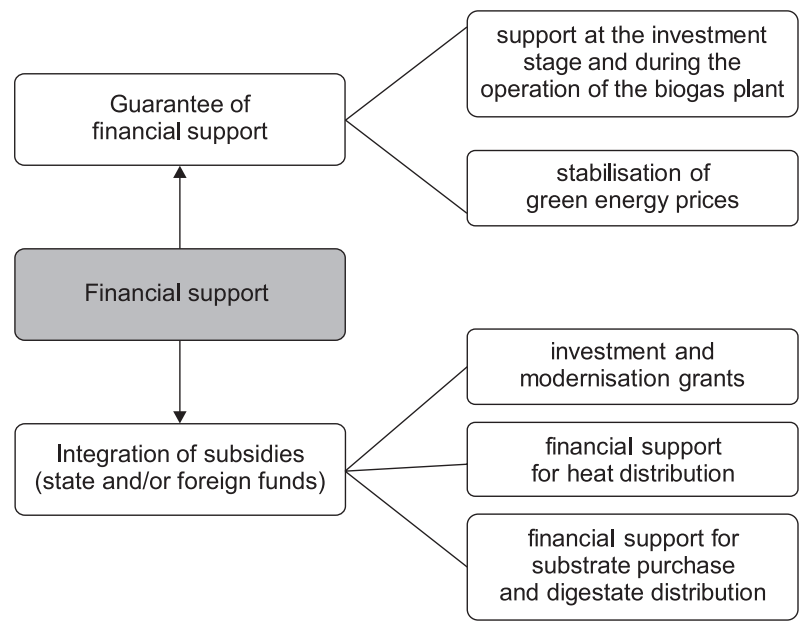

Fig. 3. Financial support for the agricultural biogas market in Poland.

Source: own study based on research results. 
enabling the creation of an appropriate profit, economically justifying the existence of the biogas plant. Actions of this kind, being a response to the worsening situation of the company, were observed in both analysed biogas plants. In the case of the biogas plant in Buczek, significant transformations took place at the stage of obtaining raw materials for biogas production. The main group of substrates came from waste from agri-food processing instead of agricultural crops, mainly maize:

"...we came to the conclusion that we have nothing to lose and we started to dispose of waste from agri-foodstuffs" (a biogas plant representative).

The change in the structure of biogas substrates enabled the biogas enterprise to open up to a new waste management market and generate additional revenues from the disposal of organic waste from the agri-food industry. Transformations are also observed at the final stage. Apart from selling electricity, the biogas plant distributes digestate used as organic fertiliser by local farmers. Similarly, the biogas plant in Działyń takes steps to dynamise the development and diversification of economic activity. In addition to the sale of organic fertilser (in liquid and solid form), the biogas plant also offers fuel briquettes as products obtained from digestate:

"We produce briquette for burning from dry digestate" (a biogas plant representative); “...they take digestate from us as manure (...). The yields from this are good" (a biogas plant representative).

The changes taking place in the functioning of the biogas plants, including those related to the remodelling of the structure of raw materials, influence the scope and pace of the relations of biogas plants with the local environment, as well as the public perception of biogas activities. In the case of both investigated biogas plants, the implementation of the investment was preceded by public consultations, meetings with local stakeholders and residents, as well as study trips to other localities:

"There was some resistance (...) people were transported to other biogas plants in order to show them that there is no danger, no smell nuisance, certainly not greater than current smells that result from running a farm" (a biogas plant representative); "There are trips from local towns - they watch and they become convinced to accept the installations" (a biogas plant representative).

Investors' involvement in local projects and dialogue with residents resulted in the acceptance of new energy actors and their operating conditions. Considering that acceptance is not a fixed construction, but rather a process (Frantal et al. 2018), the obtained approval changes over time under the influence of various factors. According to the conducted research, the key premises modifying the level of public awareness and acceptance include instability of energy policy and systemic changes in the scope of legal regulations and financial support. As mentioned above, they shape biogas plants not only at the investment stage, but also during their operation, resulting in, e.g. the search for new substrates for biogas production that provide new, additional income for the company. The changes that take place after the commissioning of the biogas plant, consisting in the reshaping of the functioning of the entire enterprise, are subject to social confrontation. The process of maintaining public acceptance of biogas activities on a given site is extremely absorbing and requires commitment, first and foremost from biogas plants, but also from the local community. This situation becomes even more multidimensional when the business model used is modified and the introduced changes may arouse public opposition:

"they should take more account of the technological regime" (a local government official).

The correction of the substrate structure consisting in increasing the importance of organic waste from agri-food production and supra-local and supra-regional suppliers is not conducive to social acceptance which has been expressed in the context of the use of local products by biogas plants, mainly of agricultural origin:

“...yes, we agreed to a certain technology when issuing a certain decision at the beginning before commissioning and all the authorities approved it, but now, during the operation of the facility, the technology is slightly changed (...). It causes local conflicts" (a local government official). 
Considering the acceptance and public reception of the biogas plants by individual social groups living in a given area, it should be underlined that a biogas enterprise is welcomed by the persons most involved in its activities, including local suppliers of substrates for biogas production, i.e. entities from the agri-food industry and farmers - buyers of digestate. The distribution of ecological organic fertiliser was well received by local farmers, mainly due to the almost cost-free acquisition of this product. A positive perception of biogas plants is also characteristic of key participants of local socio-economic life, including representatives of public institutions and local authorities, as well as residents who have the opportunity to learn and experience the non-energy results of the operation of a plant in a given area, including: new workplaces, participation in public services, support for local initiatives.

"For me as a resident (...) there is a light at the end of the tunnel that something is happening, there are some investments. Subsidising the fire brigade, equipment, uniforms... We lacked that cooperation here, we had so few of these companies $(\ldots)$ ) (a resident).

"We go directly to Działpol because it is a local company" (a local leader).

The attitudes negating the legitimacy of biogas plant operation were noted among newcomers, as well as among those not related to the agrifood industry. The representatives of these social circles do not benefit directly from the company's profits, and like other residents, they bear the costs associated with its functioning (including noise, increase in road traffic, odour nuisances) (Fig. 4). The newcomers, migrating mainly from cities, expect a cultural landscape and rural areas devoid of new anthropogenic elements, including those related to an agricultural biogas plant: "...you can cooperate very well with the locals, they understand that if there is a plant (...) it is connected with some inconvenience, whether smell or transport (...). The newcomers (...) expect the countryside to be devoid of smells associated with the countryside. For me it is absurd, it is hard to expect an idealistic village." (a biogas plant representative).

It is a key issue affecting the perception of the company that local residents can somewhat participate in the company's profits, especially in the form of heat from a biogas plant. The use of environmentally friendly, cheap, locally produced heat can provide local communities with some kind of compensation.

Research shows that changes in the way biogas plants operate due to the lack of integration between legislative support which is primarily the responsibility of national authorities, and financial support which is mainly based on international funds, including European funds, shape the relation and public perception of biogas plants (Fig. 5). The modification of the substrate structure related to the emergence of subsequent consequences of business operations felt by local communities does not benefit the overall perception of the biogas plant. On the other hand, public awareness and positive perception of agricultural biogas plants determine the tempo and scope of energy transformation at the local level. By way of comparison, the Czech Republic, one of the European leaders in biogas and biomass energy production, has experienced the integration of institutional support. Financial support is carried out on the basis of state funds. The national authorities also guarantee relevant systemic solutions regulating the biogas market in the Czech Republic. The harmonisation of both types of activities (legislative and financial) safeguards continued public aid at the central level, and precise criteria for the functioning of biogas plants, also regarding the substrate structure, limit the

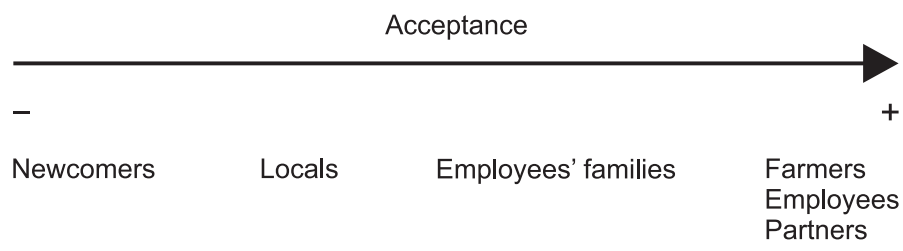

Fig. 4. Social acceptance of biogas plants.

Source: own study based on research results. 


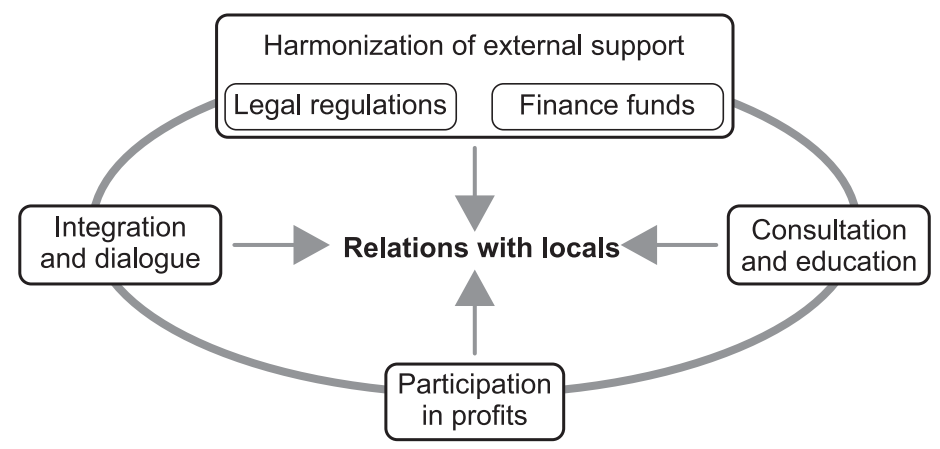

Fig. 5. Determinants of relations of biogas enterprises with the local structure. Source: own study based on research results.

possibility of conflicting situations between biogas plants and local entities. In Poland, however, the regulations governing the operation of biogas plants are not specified in detail. To date, no monitoring or management instruments applicable at local level have been developed:

“We lack legislation. We only transfer certain practices as local government officials. There is (...) some kind of a code of good practice" (a local government official).

\section{Conclusions}

The spread of energy production from renewable sources, including agricultural biogas, undoubtedly requires external support, both in legislative and financial terms. According to the research, legal solutions regulating the agricultural biogas market in Poland should be characterised by a greater degree of integration with the offered financial aid, both at the national and international (EU) level. Endeavours to harmonise the activities carried out at legislative and financial levels will ensure a systemic approach to issues related to the production of agricultural biogas and energy from biogas. Current legal and financial instruments do not guarantee success in terms of increasing energy production from RES. Financial aid for the start-up of a bioenergy power plant does not condition the efficiency of a biogas enterprise at the operation stage, as the proper functioning of the entity is influenced by the changing legal framework, which also determines the price for the production of so-called "green energy". In order to improve the economic condition of biogas enterprises, owners of biogas plants not only reduce the costs of running a business, but also look for new sources of income.

The implementation of new developmental impulses is connected with the re-modelling of the hitherto functioning of an agricultural biogas plant, primarily at the stage of obtaining substrates for biogas production. Adjustments made during the company's operations, including those related to changes in the structure of substrates, are not always in line with the expectations of the local environment. Taking into account the fact that biogas plants are located and operate in a specific local system and location, public awareness of biogas projects and their public perception impact further functioning of biogas plants, as they determine the importance of the role of institutional factors and energy policy in the energy transformation (Stephenson et al. 2011; Nakata et al. 2011).

The approval of new energy actors requires their involvement in social and economic local structures. Research shows that integration is achieved not only through meetings, dialogue and consultation with the local community at the pre-investment stage, but also has a much broader dimension covering the operation phase of the biogas plant. Biogas investors are involved in the local environment, e.g. by participating in the implementation of public services or projects for the local community. Intensified and diversified relations between biogas plant owners and residents at every stage of the company's operation, including during significant modifications, enables them to increase the democratisation of decisions constituting the basis for long-term and sustainable transformations in the energy sector (Selman 2010). For this reason, among the 
desirable personality traits of biogas entrepreneurs, should be openness and transparency, favouring the deepening of interactions and familiarisation with local conditions (Fig. 5).

All in all, the success of biogas projects and the entire energy transformation process depends, on the one hand, on the harmonisation of activities at the central, national level and, on the other hand, on taking into account the specific socio-economic features that characterise the location of the biogas plant. Therefore, providing comprehensive institutional support to biogas enterprises requires equipping local institutions, including local authorities, with appropriate instruments to shape and monitor the agricultural biogas market at the local level.

\section{Acknowledgements}

I would like to express gratitude to the people, who helped during the research, including the respondents to the interviews for providing data and materials necessary for this study.

This work was supported by the National Science Centre, Poland, Project no. 2016/21/D/ HS4/00714: Biogas enterprises from the perspective of the embeddedness concept.

\section{References}

Bluemling B., Mol A.P.J., Tu Q., 2013. The social organization of agricultural biogas production and use. Energy Policy 63: 10-17. DOI: https://doi.org/10.1016/j.enpol.2013.08.035

Buzar S., 2007. Energy poverty in Eastern Europe. Hidden geographies of deprivation. Ashgate Publishing Company, Burlington.

Chodkowska-Miszczuk J., 2014. Odnawialne źródła energii i ich wykorzystanie jako nowe trendy na obszarach wiejskich (Renewable energy sources and their use as new trends in rural areas in Poland). In: Wójcik M. (ed.), Regionalny wymiar przemian polskiej wsi - aspekty społeczne i środowiskowe (Regional dimension of Polish rural changes - social and environmental aspects), Studia Obszarów Wiejskich 35: 227-241.

Chodkowska-Miszczuk J., Biegańska J., Środa-Murawska S., Grzelak-Kostulska E., Rogatka K., 2016. European Union funds in the development of renewable energy sources in Poland in the context of the cohesion policy. Energy $\mathcal{E}$ Environment (Brentwood) 27(6-7): 713-725. DOI: https:// doi.org/10.1177/0958305X16666963

Chodkowska-Miszczuk J., Kulla M., Novotny L., 2017. The role of energy policy in agricultural biogas energy production in Visegrad countries. Bulletin of Geography. Socio-economic Series 35: 19-364--DOI: http://dx.doi. org/10.1515/bog-2017-0002
Frantál B., Van der Horst D., Martinát S., Schmitz S., Teschner N., Silva L., Golobic M., Roth M., 2018. Spatial targeting, synergies and scale: Exploring the criteria of smart practices for siting renewable energy projects. Energy policy 120 : 85-93. DOI: https:// doi.org/10.1016/j.enpol.2018.05.031

Hammersley M., 1992. What's wrong with ethnography? Methodological explorations. Longman, London.

Huber M.T., 2009. Energizing historical materialism: Fossil fuels, space and the capitalist mode of production. Geoforum 40(1): 105-115. DOI: https://doi.org/10.1016/j. geoforum.2008.08.004

Jasiulewicz M., 2010. Potencjat biomasy w Polsce (Potential of Biomass in Poland). Politechnika Koszalińska, Koszalin.

Kats G.H., 1991. Energy options for Hungary a model for Eastern Europe. Energy Policy 19(9): 855-868. DOI: https://doi.org/10.1016/0301-4215(91)90011-C

Kierzkowska K., 2011. Geneza, pojęcie i funkcje Krajowego Systemu Zielonych Inwestycji (Genesis, concept and functions of National Green Investment Scheme). Przeglą Prawa Ochrony Środowiska 1: 67-83.

Lawson R., Williams J., 2012. Understanding energy cultures. Prepublication copy: Accepted for presentation to the annual conference of the Australia and New Zealand Academy of Marketing (ANZMAC), Adelaide: University of New South Wales, December 2012,. Online: http:/ / www.otago.ac.nz/csafe/research/otago055641.pdf (accessed: 05 January 2019).

Lutyński J., 2000. Metody badań społecznych. Wybrane zagadnienia. ŁTN, Łódź.

Mitchell C., 2004. Special Edition: Energy policy for a sustainable future. Energy Policy 32, 17: 1887-1889. DOI: https://doi.org/10.1016/j.enpol.2004.03.008

Łucki Z., Misiak W., 2010. Energetyka a społeczeństwo. Aspekty socjologiczne. Wydawnictwo Naukowe PWN, Warszawa.

Nakata T., Silva D., Rodionov M., 2011. Application of energy system models for designing a low-carbon society. Progress in Energy and Combustion Science 37: 462-502. DOI: https://doi.org/10.1016/j.pecs.2010.08.001

Ruester S., Schwenen S., Finger M., Glachant J.M., 2013. A post-2020 EU energy technology policy: Revisiting the Strategic Energy Technology Plan. EUI Working Paper RSCAS, 39, San Domenico di Fiesole: European University Institute, Robert Schuman Centre for Advanced Studies, Florence School of Regulation.

Selman P., 2010. Learning to love the landscapes of carbon-neutrality. Landscape Research 35 (2): 157-171. DOI: https://doi.org/10.1080/01426390903560414

Shaffer B., 2009. Energy politics. University of Pennsylvania Press, Philadelphia.

Stephenson J., Barton B., Carrington G., Gnoth D., Lawson R., Thorsnes P., 2010. Energy cultures: A framework for understanding energy behaviours. Energy Policy 38: 61206129. DOI: https:// doi.org/10.1016/j.enpol.2010.05.069

Stephenson J., Lawson R., Carrington G., Barton B., Thorsnes P., 2011. Energy Cultures - a framework for interdisciplinary research. Sweden, Linkoping: World Renewable Energy Congress, 8-13 May 2011, Energy End-Use Efficiency Issues (EEE). Online: http://www.ep.liu.se/ecp/057/ vol3/036/ecp57vol3_036.pdf (accessed: 30 December 2018).

Unruh G.C., 2000. Understanding carbon lock-in. Energy Policy 28(12): 817-830. DOI: https://doi.org/10.1016/ S0301-4215(00)00070-7

Wirth S., Markard J., Truffer B., Rohracher H., 2013. Informal institutions matter: Professional culture and the 
development of biogas technology. Environmental Innovation and Societal Transitions 8: 20-41. DOI: https://doi. org/10.1016/j.eist.2013.06.002

Woźniak E., 2017. Stan biogazowni w Polsce. Materiaty problemowe CIRE. Online: https://www.cire.pl/ item,141910,2,0,0,0,0,0,stan-biogazowni-w-polsce.html (accessed: 5 March 2019).

Wójcik M., Dmochowska-Dudek K., Jeziorska-Biel P., Tobiasz-Lis P., 2018. Understanding strategies for overcoming peripherality: A Polish experience of transition. Bulletin of Geography. Socio-economic Series 40: 173-192. DOI: http:/ / doi.org/10.2478/ bog-2018-0022

\section{Web references}

Directive of the European Parliament and the Council no2009/28/WE, Official Journal of the European Union L140/16. Online: https://eur-lex.europa.eu/legal-content/EN/ALL/?uri=celex\%3A32009L0028 (accessed: 10 December 2018).
Eurostat. Online: https:/ /ec.europa.eu/eurostat/data/database (accessed: 30 December 2018).

Internet source 1: http://www.kowr.gov.pl/odnawialne-zrodla-energii/biogaz-rolniczy/wytworcy-biogazu-rolniczego (accessed: 11 January 2019)

NITS: National IT System - reports, 2007-2013. Online: https://www.funduszeeuropejskie.2007-2013.gov.pl/ AnalizyRaportyPodsumowania/Strony/KSI_raporty. aspx (accessed: 2 December 2018).

The Act of 20 February 2015 on renewable energy sources. Journal of Laws of 2015, item. 478.

National Fund for Environmental Protection and Water Management (NFEP\&WM). Online: http:/ / nfosigw.gov. pl (accessed: 2 December 2018).

Sprawozdanie z działalności Agencji Rynku Rolnego w 2012 r. (Report on the activities of the Agricultural Market Agency in 2012), Warszawa: Agencja Rynku Rolnego, 2013. Online: www.kowr.gov.pl/uploads/pliki/ analizy/sprawozdanie_2012.pdf (accessed: 24 March 2019). 